\title{
25 Research Square \\ Changing Medical Education Scenario: A wakeup call for reforms in Anatomy Act
}

Rekha Lalwani

All India Institute of Medical Science - Bhopal https://orcid.org/0000-0002-3927-6069

Sheetal Kotgirwar

All India Institute of Medical Science - Bhopal

Sunita A. Athavale ( $\nabla$ sunita.anatomy@aiimsbhopal.edu.in )

Research article

Keywords: Cadaver, Dissection, Medical Education, Southeast Asia

Posted Date: October 10th, 2019

DOI: https://doi.org/10.21203/rs.2.15765/v1

License: (9) This work is licensed under a Creative Commons Attribution 4.0 International License.

Read Full License

Version of Record: A version of this preprint was published at BMC Medical Ethics on July 25th, 2020. See the published version at https://doi.org/10.1186/s12910-020-00507-0. 


\section{Abstract}

Background Anatomy Act provides legal ambit to medical educationist for the procurement of cadavers. The changing medical education scenario and socio-demographic change has necessitated an urgent review of the concerned legal framework. Suitable amendments addressing the current disparities and deficiencies are long overdue.

Methods Anatomy Act in India is a state act and which ensures provision of unclaimed /donated bodies for Medical Education and research. The methodology included three components namely: Comparison of various Anatomy Acts clause by clause; Feedback from anatomist; Formulation of comprehensive model Anatomy Act.

Results Various acts studied showed discrepancies in purpose of the act, roles and duties of stake holders, regulation for body donation, procedure to handle unclaimed bodies, disposal of dissected bodies etc. None of the acts defines a donor and neither addresses the issue of transport of anatomical material. Only ten states have a clause for body donation. Acts of only six states have been amended over last 50 years. Three states denied having an act. The whole exercise of review of acts and extensive feedback received from end-users culminated in drafting of a comprehensive model Anatomy act.

Conclusion India, with the largest number of medical colleges is not only at forefront but also a hub of medical education in Southeast Asia region. A legal reform can be a torch bearer for other countries of the region with similar socio-demography and shall motivate anatomic fraternity across the globe for critical analysis of their respective anatomy acts. Keywords : Cadaver; Dissection; Medical Education; Southeast Asia.

\section{Background}

Anatomy, the study of the structure of the human body is one of the first, most basic and yet one of the most important subjects studied by medical students when they begin their medical career [1]. Teaching and research in anatomy is mainly based on cadaver dissection. A sound knowledge of anatomy is essential from the beginning of medical education and knowledge obtained through dissection of human body is an indispensable part of the education of health care professionals [2].

Dissection, as a way of acquiring medical knowledge, existed since the ancient world. Earliest reference for legally acquiring cadaver for dissection dates back to eighteenth century. The Murder Act, 1752 stipulated that the corpses of the executed murderers could be used for dissection. But by the early nineteenth century, the rise of medical science, occurring at the same time a reduction in the number of executions, had caused demand to outstrip supply [3].

To impress the necessity for altering the law upon the government, an Anatomical Society was formed around 1810. The efforts of this body gave rise to formation of a select committee to report on the question in 1828. During eighteenth century events of rise in criminal practices for acquiring cadaver, 
which led to several convictions, further pressed for a Bill. As results of these efforts the Anatomy Act 1832 (2 \& 3 Will. IV c.75) was passed in United Kingdom Parliament. It gave legal license to teachers and students of anatomy to dissect donated bodies [4].

In India, this initiative, which provided legal process of procurement of cadavers for anatomical examination for anatomy educationist, came in the form of Coroners Act in 1871 which was amended in 1949 as Bombay Anatomy Act, 1949 [5].

In Independent India, Anatomy Act is a state act promulgated by the legislature and published in the state government gazette [2].Every state ought to have one. So each state formulated its own Anatomy Act and with changing times, some were amended at different times $[5,6,7,8,9,10]$.

The scenario of medical education is changing rapidly since last 25 years, the number of medical colleges and thus the number of medical students has increased exponentially leading to increased requirement of cadavers for medical teaching and research. The source of cadavers is gradually shifting from unclaimed bodies to donated ones [2].

The editorial of Journal of Anatomical Society of India which is an official document of Anatomical Society of India in 2002 has urged the need of formulation of a draft act, it states that 'As discrepancies exist, betwixt any two or more such state acts, there is an impending and imminent need to amend, bringing in uniformity. A draft act should be made for all the states to use as model of guiding principles for amendment of Anatomy acts. This draft should contain all possible aspects well covered as perceived, after going through the acts of different states' [11].

Anatomy acts of various states in India differ on following counts:

- Purpose of the act

- Roles and duties of stake holders

- Regulation of body donation

- Procedure to handle unclaimed bodies

- Maintenance of records

- Handling of disputes

- Penalty

- Disposal of dead bodies.

Certain key areas like transport and transfer of anatomical material and definition of donors are missing in the Acts

The anatomists as the end users of the Anatomy Act are expected to lawfully procure and be in lawful possession of the anatomical material obtained from dead bodies (bones and cadavers). While regulatory bodies insist on availability of anatomical material for teaching and research in medical 
institutions, however the available acts fall short in their provisions for the same [5-10,12-22]. In contrast, The Transplantation of Human Organs and Tissues Act [23], enacted in 1994, is a comprehensive act in which responsibilities and duties of all stake holders are clearly defined. This act is uniformly applicable throughout India.

Although anatomists of India express the pressing need for a uniform, comprehensive act as resolved in general body meeting of national conference of Anatomical society of India, 2013, such an effort still wanted [24].

Hence the authors took up this task of formulation of comprehensive draft anatomy act with objectives to

- study the Anatomy Act of various states and Union Territories of India

- compare the various provisions of Anatomy acts of different states and Union Territories of India

- identify deficiencies and discrepancies in the provisions of the Act in various states and Union Territories of India

- Seek suggestions from end users regarding addition/ deletion/ modifications in various provisions of the Anatomy Act.

- Formulate a comprehensive Draft Model Anatomy Act.

\section{Methods}

The study was initiated after approval from Research and Review board (RRB) and Institutional Human Ethics Committee (IHEC) of our institute. The draft Anatomy Act has been prepared through review of Anatomy Acts of various states \& Union Territories and wide consultation with anatomy fraternity.

The process included three components namely:

Review of Anatomy acts of various states.

Inputs from the end users i.e. Anatomy departments of medical colleges.

Formulation of a draft model act.

\section{Review of Anatomy acts of various states:}

The original and amended Anatomy Acts of various states and Union Territories of India were procured by downloading the acts through the internet from official websites. In case of unavailability from internet Right To Information (RTI) queries were sent to the health secretariat of state and Union Territory of Union of India to procure a copy of the act (Table I). The various provisions of the acts were thematically analyzed in a tabulated form. Deficiencies and discrepancies in the acts of various states were analyzed, considering the changing medical education scenario. 


\section{Inputs from the Anatomist:}

Information along with informed consent was sought from the Head, Department of Anatomy of all approved medical institutes of Union of India. The information regarding difficulties encountered during procurement of unclaimed or donated cadavers and suggestions were sought on possible improvements/ modifications in the present Anatomy Act of their respective states. The information seeking questionnaire was sent first time by speed post and for non-responsive end users it was sent again along with self addressed stamped envelope.

The problem statements of existing Anatomy Acts, highlighting the deficiencies and discrepancies and possible modifications clause by clause were presented at National conference of Anatomical Society of India at Imphal, 2014 and Society of Clinical Anatomist at Amritsar in 2016. The views of eminent anatomists present there were sought and documented.

\section{Formulation of a model act:}

Considering the need of current scenario of medical education suitable modifications in the acts are proposed and a model act has been formulated.

\section{Results}

We could obtain original/amended Anatomy Acts and Bill from eighteen states and union territories [5$10,12-22]$. Three states confirmed in response to an RTI query that there is no Anatomy Acts in their state. Fourteen states and/ union territories did not respond to RTI query nor could the authors get act from internet/stakeholders. In one state (Manipur) the act was still a bill and was yet to be enacted [19]

The problem statement and comparison of various clauses of the act is as follows:

These sections mentioned are as per the Gujarat Anatomy Act [15]. These sections may differ serially in different acts.

Act starts with the Statement of Objects and Reasons, which states the purpose (Table III) for which the act has been enacted. The purpose does not include the use of donated bodies in twelve states namely $\mathrm{KL}, \mathrm{TN}, \mathrm{GA}, \mathrm{GJ}, \mathrm{HP}, \mathrm{HR}, \mathrm{PB}, \mathrm{CH}, \mathrm{SK}, \mathrm{UP}, \mathrm{MP}$ and $\mathrm{AS}[8,10,12,14-18,20-22]$

Section: Short title, extent and commencement.

This section is uniformly similar across all acts and contains the year of enactment and amendments thereof.

Section: Definitions 


\section{Approved institute}

All the Anatomy Acts available to us include medical teaching institutes as approved institutes for the purpose of act. But acts of MH, OD, TN, GA, GJ, HP, HR, PB, CH, MP and MN also include standalone Hospitals (not attached to any medical teaching institute) as approved institutes $[5,9,10,14-17,18$, $19,20]$

\section{Authorized officer}

Authorized officer are the officers competent to act for the purpose of act especially in cases of handling of unclaimed body.

In all acts officers appointed or authorised to act under this Act shall be deemed to be public servants within section 21 of the Indian Penal Code, 1860 (Central Act 45 of 1860).

\section{Unclaimed body}

All available Anatomy Acts define unclaimed body-as body of deceased person who has no near relative. Claimants recognized by various Anatomy Acts of the body of deceased apart from near relatives are shown in table IV.

Acts of several states have included section for body donation but no act has defined a donor.

Section: Power of state government to authorise officer to act under section (Section: Procedure to handle unclaimed bodies):

In Assam, a notification of state government clarified that police officer having jurisdiction over the area is the authorized officer [12]. In Punjab government notification; the principals of the government medical colleges are the authorised officers for the purpose of the act. Whether such notification has been issued by other state governments is not known/available to us.

Section: Unclaimed dead bodies in hospitals, prisons and public place how to be dealt with:

All Anatomy Acts have clearly laid down procedure to handle the unclaimed bodies but the procedure differs from state to state.

The states namely HP, HR, PB, CH, SK and MP only mention the duty of authorized officer on intimation of unclaimed body that it is to be taken inpossession with least practicable delay and handed over to approved institute, or be disposed of in the manner prescribed $[16,17,18,20,21]$. But there is no mention regarding suspicious death. States namely $\mathrm{MH}, \mathrm{DL}, \mathrm{KA}, \mathrm{KL}, \mathrm{TN}, \mathrm{UP}, \mathrm{AS}$ and $\mathrm{MN}$ also describe the procedure to be followed, if there is suspicion regarding the cause of death $[5,7,8,10,13,22,26]$. It is then necessary to send the body for post mortem examination. Gujarat Anatomy Act, 2011 states that on 
suspicion regarding cause of death, inquest (police) is to be done subsequent to which the body may be handed over to the approved institute or sent for post mortem examination as per findings of inquest [15].

Section: Doubt or dispute as to near relative to be referred to Magistrate of the First Class -Uniformly similar across all acts.

Section: Donation of bodies or any part thereof deceased persons for anatomical examination etc.

Of the available acts, acts of eight states namely TN,GA, HP, HR, PB, CH,MP and AS do not have any provision for donation of body[10,13,14,16,17,18,20]. Acts of $M H, K A, O D$ and $M N$ clearly indicate the procedure to be followed in cases when the death of an interested donor occurs at home $[5,7,9,19]$.This includes provision of acceptance of death certificate stating the manner and cause of death as per his/her best knowledge by a registered medical practitioner who may or may not have attended the deceased person in last seven days. This registered medical practitioner however should not be concerned in dealing with body donation.

Section: Maintenance of records

Except for MH, DL and GJ no other state has included maintenance of record in their acts $[5,6$, 15].Maharashtra Anatomy Act clearly lays down the manner in which the records have to be maintained, specifies the entries and duties of concerned authorities in a time bound manner [5].

Section: Refusal to accept unclaimed / donated body

Different states have different clauses with regards to the refusal to accept a donated /unclaimed body by the approved institute as shown in table $\mathrm{V}$.

Section: Disposal of dead body

None of the acts have included the clause for the disposal of the dead body after its use except for three states i.e. $\mathrm{MH}, \mathrm{OD}$ and $\mathrm{GJ}[5,9,15]$.While OD and GJ have mentioned the disposal in prescribed manner, Maharashtra act has dealt with this issue in detail prescribing the manner in which the said disposal should happen as per the religious persuasion of deceased $[5,9,15]$. The authorized institute is required to transfer the information of disposal to the executive magistrate or any other officers as approved by state government within a stipulated time.

Section: Penalty

All the available acts include a provision for punishment of person who obstructs any process laid down in the act. This punishment varies in different acts and ranges from penalty of $200[16,17,20]$ to 5000 $[15,19]$ and even with provision of imprisonment up to 6 months [9].

Section pertaining to Duty of Police and other officers to assist in obtaining possession of unclaimed bodies; Protection of persons acting under this Act and officers to be public servants-were similar across 
all acts.

Section: Act not to prohibit post-mortem examination

Following states namely $\mathrm{MH}, \mathrm{DL}, \mathrm{KA}, \mathrm{OD}, \mathrm{KL}, \mathrm{GJ}, \mathrm{SK}, \mathrm{UP}, \mathrm{AS}$ and $\mathrm{MN}$ have a clause stating that nothing in Anatomy Acts prohibits post mortem examination if there is suspicion regarding cause of death $[5,6,7,8$, $9,15,19,21,22]$

Section: Power to make rules: All acts provide power to state government to make rules/amendment.

Section: Transfer and transport of cadavers and anatomical material amongst the authorized institute.

While no act has a section addressing transfer and transport of cadavers amongst the approved institute. Government of KA, by gazette notification, has framed the rules and regulation regarding the same in 2005 [27]. Any such notification by any other state government could not be obtained.

The suggestions and views of sixty six respondents received in response to questionnaire addressing various sections of Anatomy Acts are as follows (Table VI)

\section{Discussion}

Review of available Anatomy Acts highlights glaring discrepancies and deficiencies across various clauses of the acts. While some states like MH, KA, KL etc. have amended the acts with changing times, many states still continue with outdated acts which are not in tune with the changed medical education scenario and socio cultural fabric $[5,7,8]$.

State reorganization has resulted in smaller states being carved out of larger ones like UK, JH, CG, TS. These states need to adopt Anatomy Act with suitable amendment.

As the medical teaching institutes are increasing in number and expanse, they have out reached even the states earlier not having such institutes. Such states /Union Territories also need to enact Anatomy Act as early as possible (e.g. AN, TR, ML) [25].

The provision of Anatomy Act is primarily for the purpose of getting cadavers for anatomical examination, dissection, research and etc. however inclusion of surgical operations for therapeutic purposes is out of place especially after enactment of, The Transplantation of Human Organs and Tissues Act, 1994 [23]which, under its ambit, includes use of all human tissues for therapeutic purpose. Hence surgical operations should be deleted from the purpose of Anatomy Act.

An approved institute as stated in all acts is a medical teaching institute however inclusion of standalone hospital not involved in teaching and research is unwarranted and hence should be deleted.

Key person in enactment of Anatomy Act is the authorised officer. However the definition of authorised officer as per law is very wide and includes all public servants under section 21 of the Indian Penal Code, 
1860 (Central Act 45 of 1860). In absence of government regulations as per who amongst them is the authorised officer for purpose of this act creates confusion, thus hampering the proper disposal of duties.

Communication technology has helped in identification of unclaimed bodies and hence the number of unclaimed bodies is on decline, but on other hand our socio cultural milieu is also changing with times and there are many cases encountered now days where body of deceased person is not claimed by a near relative. This is more so in case of elderly individuals staying alone.

While some states have included the provisions of claimants like personal friends, servants etc. Authors feel that in absence of near relative the claimants should be a group of persons interested, at least five in number, who should be known and associated with deceased, rather than a single individual. This is important to avoid any legal complications like property disputes.

As was observed a 'donor' was not defined even in those acts which had regulation for body donations. Authors feel that a body donor should be defined as in The Transplantation of Human Organs and Tissues Act, 1994[23].

After confirmation that the body is unclaimed the authorised officer has to ascertain the circumstances of death. Whether or not all such unclaimed bodies should be treated as suspicious death and be subjected to post-mortem examination is answered differently in different acts.

Post-mortem renders the body unsuitable for preservation and hence dries up the source of unclaimed bodies for educational institutes. Large sections of anatomists feel that a police inquest into the cause of death (ruling out foul play) should be sufficient enough and thence the unclaimed body can be handed over to the approved institute [15].

However it is also acknowledged that an inconclusive police inquest would warrant post-mortem examination. Authors are of opinion that bodies can also be handed over to the approved institutes even after post-mortem which can then be utilised for procurement of bones etc. However right to accept or refuse such body should rest with the approved institute.

While the first voluntary body donation of India happened in 1956, when the body of Late Shri Pandurang Sridhar Apte was donated to B. J. Medical College Pune [28].An increasing trend of awareness towards the noble cause of body donation for the purpose of education and research is being observed in recent times so much so that proportion of donated bodies have surpassed that of unclaimed ones in some parts of India e.g. Gujarat [29].

This necessitates the inclusion of clause of body donation in all Anatomy Acts. However this trend has also resulted in practical difficulties, legal complication etc. to obviate such difficulty and facilitate donations which are in legal ambit figure 1 explains the suggested procedure to be followed in cases of donation. This has been formulated after combining the provisions in certain acts e.g. MH, GJ and views of key users $[5,15]$. 
While the documentation is very important where ever legal process are involved only Anatomy Acts of three states i.e. MH, DL and GJ have included prescribed the manner in which the records have to be maintained $[5,6,15]$. Authors feel that this clause should necessarily be included in all acts.

There are many circumstances where the officer in charge of an approved institute is compelled to refuse a donated or unclaimed body. Such circumstance may be:

- Body unsuitable for embalming/preservation

- Infectious bodies which are hazardous for handlers

- Medico legal cases

- Lack of infrastructure and resources which limit the proper storage and handling of bodies (cadavers)

- Any other reason as deemed fit by senior faculty of Anatomy department.

This warrants the provision of refusal of body that should rest with approved institute.

Increasing awareness about body donation have resulted in increasing queries regarding disposal of dead bodies after their use especially by near relatives. To ensure respectable disposal of human bodies and its parts thereof, it must be prescribed by all acts. Though this is prescribed in Maharashtra Anatomy Act but is least practical and hence needs simplification [5]. Anatomists feel that decent cremation in consecrated ground is both practical and respectful.

Clause for penalty for 'whosoever abets the disposal of or obstructs any officer in execution of Anatomy Act' is present in all available acts, however the penalty varies drastically. Authors support a harsher penalty with the provision of imprisonment as included in the Odisha Anatomy (Amendment) Act, 2012 [9].

There are disparities in the cadavers available for teaching and research across states between institutes and amongst the government and private running institutes also. While some states and institutes have surplus cadaveric material (sometimes causing difficulty in storage and handling of cadavers) whereas severe dearth of cadavers in some states and institutes is adversely affecting the learning and training of medical students. In absence of any clause for transfer of anatomic material from one approved institute to another any transport is thus considered illegal as of now. Inclusion of such a clause would ensure equitable distribution, thus ensuring equal standards in medical education. Inclusion of such a clause is an overwhelming demand of almost all anatomists.

Authors suggest that a nodal centre having a registry of unclaimed or donated cadavers can also aid in ensuring uniform distribution.

The whole exercise of review of acts and extensive feedback received from end-users culminated in drafting of a comprehensive model Anatomy Act which has incorporated best of provisions of various Anatomy Acts and some modifications and inclusions as suggested by key users (Annexure A). 


\section{Conclusion}

Authors present a draft Anatomy Act addressing the disparities and deficiencies in the existing Anatomy Acts of various states and union territories of India and also considering the changing medical education scenario and socio-cultural fabric. This act ensures the provision of cadaveric material for teaching and training of medical students under legal ambit. It is also expected to guide law makers to make suitable amendments to existing legislation. It is also expected to serve as a reference document for anatomic fraternity across the globe to critically analyse their respective anatomy acts.

\section{Declarations}

- Ethic's approval and consent to participate: Ethical approval was granted for the study by Institutional Human Ethics committee, All India Institute of Medical Sciences, Bhopal, India (IHEC-LOP /2014/IM00019). Consent to participate: Written informed consent from stake holders obtained.

- Consent to publish: Not applicable

- Availability of data and materials: The dataset/documents used and/or analyzed during the current study are available from the corresponding author on reasonable request.

- Competing interests: None to declare.

- Funding: Not applicable.

- Acknowledgements: Not applicable

- Authors' contributions: RL, SK and SAA designed the study and data collection instruments. RL and SAA analyzed, interpreted the data, and wrote the first draft. All authors read and approved the manuscript.

\section{References}

1. Riederer BM. Body donations today and tomorrow: What is best practice and why? Clin Anat. 2016; 29(1):11-8. doi: 10.1002/ca.2264. 2. Ajita R, Singh Yl. Body donation and its relevance in anatomy learning- A review. J.Anat.Soc. 2007;India 56(1): 44-47. 3. Woods GD. A History of Criminal Law in New South Wales: The Colonial Period, 1788-1900. Federation Press, New South Wales; 2002. 4. Fraser HD. History of the events which led to the passing of the British Anatomy Act, A.D. 1832. Can Med Assoc J. 1920; 10(3): 283-284. 5. Bombay Anatomy Act, 1949. Bombay Government Gazette Part V page 65(22.4.1949), Government of Bombay. Available from: bombayhighcourt.nic.in/libweb/acts/1949.11. Accessed 18 January 2014. 6. Delhi Anatomy Act,1953. Government of National Capital territory of Delhi. Available from: https://www.legalcrystal.com/act/134716/delhi-anatomy-act-1953-complete-act.

Accessed 18 January 2014. 7. The Karnataka Anatomy Act, 1957. Karnataka Gazette (2014) L.A. Bill No. 1 of 1998. File No. LAW 25 LGN 97 (11.07.2014) Department of Parliamentary Affairs and Legislation, Government of Karnataka. Available from: http://dpal.kar.nic.in/pdf_files/23\%20of\%201957\%20(E).pdf. 
Accessed 23 January 2014. 8. The Kerala Anatomy Act, 1957. The Kerala Gazette. Act 3 of 1964, Act 23 of 1988. Government of Kerala. Available from:

https://archive.org/stream/1957KERALA17/1957KERALA17_djvu.txt Accessed 23 January 2014. 9. The Odisha Anatomy (Amendment) Act, 2012. The Odisha Gazette No.5728-Legis-28/2012/L.(3.6.2013) Law Department, Government of Odisha. Available from: http://odisha.gov.in/govtpress/pdf/2013/1058.pdf. Accessed 28 January 2014. 10. The Tamil Nadu Anatomy Act,1951. Available from:

http://www.lawsofindia.org/pdf/tamil_nadu/1951/1951TN18.pdf. Accessed 28 January 2014. 11. Patnaik GVV. Editorial. J. Anat. Soc. India.2002; 50(2): 143-144. 12. The Assam Anatomy Act, 1972. Department of Health and family Planning Government of Assam. 13. The Bihar Anatomy Act, 1961. Act No. 7 of 1961. Bihar Government Gazette, Government of Bihar. 14. The Goa, Daman and Diu Anatomy Act, 1976. Act No. 21 of 1976 Official Gazette Series I, No. 34 dated 18-11-1976. Government of Goa, Daman and Diu. Available from: http://goaprintingpress.gov.in/uploads/Anatomy Act.pdf Accessed 18 January 2014. 15. The Gujarat Anatomy Act, 2011. Act No. 10 of 2011The Gujarat Government Gazette ,Government of Gujarat. Available from:

http://www.lawsofindia.org/statelaw/74084/TheGujaratAnatomyAct2011.html Accessed 23 January 2014. 16. The Haryana Anatomy Act, 1974. The Haryana Government Gazette (5.8.1974). Government of Haryana. Available from: http://www.lawsofindia.org/pdf/haryana/1974/1974HR24.pdf Accessed 23 January 2014. 17. The Himachal Pradesh Anatomy Act, 1966. Act No. 4 OF 1966(8.2.1966), Government of Himachal Pradesh. Available from: http://archive.india.gov.in/allimpfrms/allacts/664.pdf Accessed 23 January 2014. 18. The Madhya Pradesh Anatomy Act, 1954. Act No. 16 of 1954. The M.P. Government Gazette (12.4.1958). Government of Madhya Pradesh. 19. The Manipur Anatomy Bill, 2015. Bill No. 15 of 2015. Government of Manipur. 20. The Punjab Anatomy Act, 1963. The Punjab Government Gazette. Government of Punjab. Available from: http://www.lawsofindia.org/pdf/punjab/1963/1963PN14.pdf. Accessed 28 January 2014. 21. The Sikkim Anatomy Act, 2014. The Sikkim Government Gazette, Law Department, Government of Sikkim. 22. The Uttar Pradesh Anatomy Act, 1957. Act No. 6 of 1957. The U.P. Government Gazette extraordinary Government of Uttar Pradesh. 23. The Transplantation of Human Organs Act, 1994. The Legislative Department of the Ministry of Law and Justice, Government of India. Available from: http://www.indiacode.nic.in/fullact1.asp?tfnm=199442 Accessed 18 January 201424. Minutes of the General Body meeting (GBM) of Anatomical Society of India, 2013. No. ASI/14-Min (ii) / Secy-8 (5.2.2014) Available from: http://asiindia.in/web/Portals/0/Files/Meetings/GBmin2013.pdf. Accessed 18 January 2014. 25. Medical council of India. List of colleges teaching M.B.B.S. Available from: http://www.mciindia.org/InformationDesk/ForStudents/ListofCollegesTeachingMBBS.aspx Accessed 10 April 2017. 26. Guidelines for cadaver and whole body deceased donation , 2014. No. 14/02/Misc/H \& FW/2013/ 8110-20(5.9.14) Government of National Capital territory of Delhi. Available from:

http://dshm.delhi.gov.in/mis/(S(mr4go54ormtlapcdwm1vhxux))/orders/Guidelines_for_cadaver.pdf Accessed 18 January 2014. 27. Rules and Regulation for transfer of cadaver from one college to another Medical College, 2005. No. 183/MSF/2005/17.09.2005. Government of Karnataka. 28. Dope SA, Bhusari PA, Kulkarni PR, Diwan CV. Body donation -The life after death. MedPulse - International Medical Journal 2015; 2(4): 216-220. 29. Twitter account of Mr NarendraModi. Available from: 
www.narendramodi.in/gujarat-is-on-top-in-donation-of-blood-eye-and-body-cm-4380. Accessed 10 April 2017.

\section{Tables}

Table I shows the mode of procurement of Anatomy Act of respective states and Union Territories.

\begin{tabular}{|c|c|c|c|}
\hline S.no & $\begin{array}{l}\text { Mode of } \\
\text { obtaining } \\
\text { Anatomy Act }\end{array}$ & Number & States and Union Territories \\
\hline 1. & Website & 11 & $\begin{array}{l}\text { Maharashtra (MH) [5], Delhi(DL) [6, 26], Goa (GA) [14], Gujarat (GJ) } \\
\text { [15], Haryana (HR) [16], Himachal Pradesh (HP) [17], Karnataka (KA) [7] } \\
\text {,Kerala(KL) [8] , Punjab (PB) [20], Chandigarh (CH) [20] Tamil Nadu(TN) [10] }\end{array}$ \\
\hline 2. & $\begin{array}{l}\text { Anatomy Act } \\
\text { received in } \\
\text { response to } \\
\text { RTI }\end{array}$ & 2 & Manipur(MN) [19] , Sikkim(SK) [21] \\
\hline 3 & $\begin{array}{l}\text { Act received } \\
\text { from } \\
\text { stakeholders }\end{array}$ & 5 & $\begin{array}{l}\text { Assam(AS)[12], Bihar (BR) [13], Madhya Pradesh (MP) [18], Odisha (OD) } \\
\text { [9],Uttar Pradesh (UP)[22] }\end{array}$ \\
\hline 4. & $\begin{array}{l}\text { No Anatomy } \\
\text { Act enacted } \\
\text { as confirmed } \\
\text { by RTI }\end{array}$ & 3 & Uttarakhand(UK) , Tripura (TR), Jharkhand(JH) \\
\hline 5. & $\begin{array}{l}\text { Act denied in } \\
\text { response to } \\
\text { RTI }\end{array}$ & 1 & Jammu and Kashmir(J\&K) \\
\hline 6. & $\begin{array}{l}\text { No Response } \\
\text { or } \\
\text { inappropriate } \\
\text { response to } \\
\text { RTI }\end{array}$ & 14 & $\begin{array}{l}\text { Andhra Pradesh (AP), Arunachal Pradesh*(AR),Meghalaya(ML),Mizoram* } \\
\text { (MZ), Nagaland*(NL), Rajasthan(RJ), Telangana(TS), West Bengal (WB), } \\
\text { Andaman and Nicobar Island (AN), Dadra and Nagar Haveli*(DN), } \\
\text { Lakshadweep*(LD), Chhattisgarh (CG), Pondicherry(PY), Daman and } \\
\text { Diu (DD)* }\end{array}$ \\
\hline
\end{tabular}

*These states and union territories do not have medical teaching institutes [25].

Table II: Showing the number and the year of amendment/s.

\begin{tabular}{|l|l|l|l|}
\hline Sr. No & State & Number of amendments & Year/s of amendments \\
\hline 1 & DL & 1 & 2014 \\
\hline 2 & KA & 2 & $1999 \& 2005$ \\
\hline 3 & MH & 2 & $1975 \& 2000$ \\
\hline 4 & KL & 2 & $1964 \& 1988$ \\
\hline 5 & TN & 1 & 1960 \\
\hline 6 & OD & 2 & $1975 \& 2012$ \\
\hline
\end{tabular}


Table III: Showing differences in the purpose of the act/s.

\begin{tabular}{|l|l|l|}
\hline $\begin{array}{l}\text { Sr. } \\
\text { no }\end{array}$ & Purpose of the Act & States \\
\hline 1 & $\begin{array}{l}\text { Anatomy examination/dissection, research purpose and other similar } \\
\text { purposes. }\end{array}$ & $\begin{array}{l}\text { All available acts of the } \\
\text { states. }\end{array}$ \\
\hline 2 & $\begin{array}{l}\text { Therapeutic and surgical operations also stated as purpose in addition } \\
\text { to point 1 }\end{array}$ & $\begin{array}{l}\text { MH,OD, TN,GA,GJ,HR,PB, } \\
\text { CH. }\end{array}$ \\
\hline
\end{tabular}

Table IV: Showing recognized claimants of unclaimed bodies besides near relative.

\begin{tabular}{|l|l|l|}
\hline S. no & Recognized Claimants of unclaimed bodies & States \\
\hline 1 & Person interested & KA \\
\hline 2 & Relatives/public institutes of religion of deceased. & KL \\
\hline 3 & Servants & UP \\
\hline 4 & Personal friends & DL, MN \\
\hline
\end{tabular}

Table V: Summaries the section of refusal to accept donated / unclaimed body

\begin{tabular}{|l|l|l|}
\hline & $\begin{array}{l}\text { Name of } \\
\text { state }\end{array}$ & Clause \\
\hline 1 & $\begin{array}{l}\text { MH, GA, } \\
\text { HP, PB, } \\
\text { SK, MP, } \\
\text { AS }\end{array}$ & No provision for refusal of unclaimed /donated bodies. \\
\hline 2 & $\begin{array}{l}\text { KA, KL, } \\
\text { TN, UP, } \\
\text { MN }\end{array}$ & $\begin{array}{l}\text { It is mentioned that authorised institute shall accept the unclaimed / donated body if } \\
\text { required. }\end{array}$ \\
\hline 3 & DL, OD, GJ & $\begin{array}{l}\text { Clearly mention the right to refuse an unclaimed /donated body. If senior officer of } \\
\text { authorised institute decides that the body is not suitable for educational purposes or the } \\
\text { body is not required by the said institute. }\end{array}$ \\
\hline
\end{tabular}


Overwhelming views and suggestions of the Anatomy fraternity of India regarding various sections/ provisions of Anatomy Acts of their respective states 


\begin{tabular}{|c|c|c|c|c|c|}
\hline \multirow{2}{*}{$\begin{array}{l}\text { S. } \\
\text { no }\end{array}$} & \multirow{2}{*}{$\begin{array}{l}\text { Questions Regarding various } \\
\text { sections of Anatomy Act of } \\
\text { their respective states }\end{array}$} & \multicolumn{3}{|c|}{ Response } & \multirow{2}{*}{ VIEWS/SUGGESTIONS OF STAKE HOLDERS } \\
\hline & & Yes & No & Nil & \\
\hline 1. & $\begin{array}{l}\text { Is approved institution clearly } \\
\text { defined? }\end{array}$ & 52 & 10 & 2 & $\begin{array}{l}\text { Although the definition of approved institute implies that } \\
\text { it includes all government/private medical and dental } \\
\text { institutes. Anatomist want approved institute to be clearly } \\
\text { spelt out either in act or in notification. }\end{array}$ \\
\hline 2. & $\begin{array}{l}\text { Is the definition of unclaimed } \\
\text { bodies clearly spelt. }\end{array}$ & 47 & 15 & 2 & \\
\hline 3. & $\begin{array}{l}\text { Is procedure to handle } \\
\text { unclaimed bodies clearly laid } \\
\text { down? }\end{array}$ & 42 & 20 & 2 & $\begin{array}{l}\text { Ways to be devised so that as bodies reach all approved } \\
\text { institutes (all government/private medical, dental and } \\
\text { allied) unbiased without performing postmortem in } \\
\text { specific time frame. } \\
\text { Authorized officer should be aware of his responsibilities } \\
\text { regarding the act. }\end{array}$ \\
\hline 4. & $\begin{array}{l}\text { Have the responsibilities of } \\
\text { authorized officer been clearly } \\
\text { defined? }\end{array}$ & 35 & 27 & 2 & $\begin{array}{l}\text { So that the unclaimed body reaches the approved } \\
\text { institute before the putrefaction sets in. }\end{array}$ \\
\hline 5. & $\begin{array}{l}\text { Is provision for receiving } \\
\text { donated bodies present? }\end{array}$ & 43 & 18 & 3 & $\begin{array}{l}\text { Overwhelming view to include this section in acts lacking } \\
\text { it. }\end{array}$ \\
\hline 6. & $\begin{array}{l}\text { Suggestion regarding } \\
\text { management of situation, when } \\
\text { donated bodies arrive at the } \\
\text { approved institute without } \\
\text { death certificate. }\end{array}$ & & & & $\begin{array}{l}\text { Should be received only along with police verification } \\
\text { report (N.O.C.), certificate from village sarpanch or } \\
\text { denied in absence of above certificates. }\end{array}$ \\
\hline 7. & $\begin{array}{l}\text { Is transfer or transport of } \\
\text { cadaveric materials mentioned? }\end{array}$ & 21 & 38 & 5 & Should be legally approved. \\
\hline 8. & $\begin{array}{l}\text { Does the Act mention the } \\
\text { maintenance of records? }\end{array}$ & 28 & 31 & 5 & $\begin{array}{l}\text { Documentation should be mandatory and clearly laid } \\
\text { down for bodies or part thereof/bones/anatomic } \\
\text { material/still birth fetus. There should be uniformity in } \\
\text { the format of body donation forms, acknowledgement } \\
\text { letter, maintenance of records of donations and unclaimed } \\
\text { bodies etc. }\end{array}$ \\
\hline 9. & $\begin{array}{l}\text { Is procedure of disposal of } \\
\text { claims by the "said relatives" } \\
\text { clearly laid down? }\end{array}$ & 23 & 37 & 4 & Should be clearly laid down \\
\hline 10. & $\begin{array}{l}\text { Is a clause for penaltyfor } \\
\text { thosewho interfere with any } \\
\text { procedure of act present? }\end{array}$ & 25 & 30 & 9 & Should be increased from Rs. $5000 /=$ to Rs. $25000 /=$ \\
\hline 11. & $\begin{array}{l}\text { Is uniformity in Anatomy Acts } \\
\text { of various states is need of the } \\
\text { day. }\end{array}$ & 53 & 8 & 3 & $\begin{array}{l}\text { Socially and demographically states are different hence } \\
\text { not possible. } \\
\text { Laws regarding handling of unclaimed body are stringent } \\
\text { in certain states which if uniformly applicable will affect } \\
\text { the availability of unclaimed body in all states. } \\
\text { Only guidelines to be issued by central government. }\end{array}$ \\
\hline 12. & Any other Suggestions & & & & $\begin{array}{l}\text { Officer who should receive the body in approved institute } \\
\text { should be clearly defined. } \\
\text { Criteria for acceptance or refusal of unclaimed body } \\
\text { should be clearly laid down. } \\
\text { National body bank registry for uniform distribution of } \\
\text { cadavers. } \\
\text { Prior informed consent from donor and/or near relative in } \\
\text { case of transfer and transport of cadaver. }\end{array}$ \\
\hline
\end{tabular}




\section{Figures}

\section{Procedure to handle Body Donation}

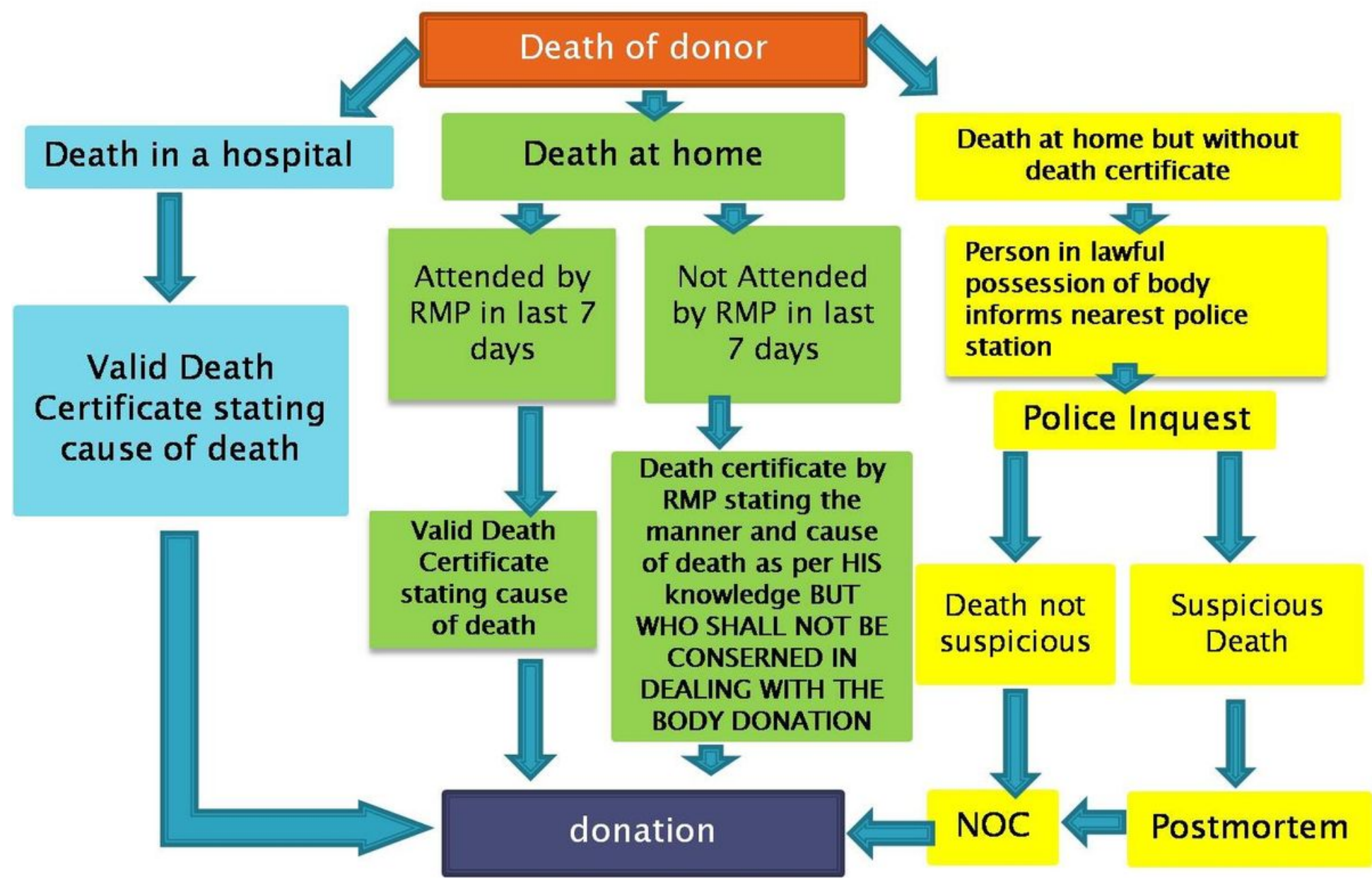

Figure 1

Procedure to handle body donation

\section{Supplementary Files}

This is a list of supplementary files associated with this preprint. Click to download.

- A.docx 